\title{
Polymorphism in the promoter region of von Willebrand factor gene and von Willebrand disease type 1
}

\author{
Daniel Simon $^{1,2}$, Eliane Bandinelli ${ }^{1}$ and Israel Roisenberg ${ }^{1}$ \\ ${ }^{1}$ Universidade Federal do Rio Grande do Sul, Instituto de Biociências, Departamento de Genética, \\ Porto Alegre, RS, Brazil. \\ ${ }^{2}$ Universidade Luterana do Brasil, Canoas, RS, Brazil.
}

\begin{abstract}
The -1185A/G polymorphism in the 5'-regulatory region of the von Willebrand factor (VWF) gene was associated with VWF plasma levels in a normal population. This study was undertaken to evaluate whether there is a relationship between this polymorphism and type 1 von Willebrand disease (VWD), a disorder characterized by a quantitative deficiency of VWF. The association between this polymorphism and plasma VWF levels in normal Brazilian individuals was also analyzed. Control subjects $(n=460)$ and type 1 VWD patients $(n=41)$ were studied. Polymerase chain reaction (PCR) amplification of the 864-bp VWF promoter region followed by Accll restriction-digestion was used to identify the $-1185 \mathrm{~A} / \mathrm{G}$ genotypes. The $-1185 \mathrm{G}$ allele frequency was $57 \%$ in normal individuals and $63 \%$ in type 1 VWD patients, this difference was not significant $(p=0.29)$. No significant association was observed between -1185A/G genotypes and VWF plasma levels in normal individuals, although VWF levels were in the same direction as those reported by another study, with subjects carrying the $G$ allele having the lower levels. These results suggest that $-1185 \mathrm{~A} / \mathrm{G}$ polymorphism is not associated with the partial deficiency of VWF in type 1 VWD patients.
\end{abstract}

Key words: von Willebrand factor, promoter polymorphisms, genetics, von Willebrand disease.

Received: June 26, 2003; Accepted: October 21, 2003.

\section{Introduction}

Von Willebrand disease (VWD) is the most frequent inherited human bleeding disorder, with a prevalence of up to $1 \%$ in the general population (Rodeghiero et al., 1987; Werner et al., 1993). It is caused by quantitative or qualitative defects in the von Willebrand factor (VWF), a multimeric glycoprotein present in megakaryocytes, platelets, endothelial cells, and plasma. VWF plays two main hemostatic roles: (a) binding of platelets to subendothelium at sites of vascular injury, and (b) stabilization and protection of coagulation factor VIII (FVIII).

VWD exhibits a wide heterogeneity of phenotypes, which are classified into three main groups (Sadler, 1994). Type 1 VWD refers to a partial, quantitative deficiency of VWF, the most frequent form of VWD, accounting for $70-80 \%$ of the diagnosed cases, and is considered as an autosomal dominant disease with incomplete penetrance and variable expressivity (Sadler et al., 1995). Type 2

Send correspondence to Israel Roisenberg. Universidade Federal do Rio Grande do Sul, Instituto de Biociências, Departamento de Genética, Caixa Postal 15053, 91501-970 Porto Alegre, RS, Brazil. E-mail: israberg@ufrgs.br.
VWD refers to all qualitative variants of VWF and is generally autosomal dominant with regard to inheritance, except for type 2N VWD which is autosomal recessive. Type 3 VWD, the severe form of the disorder, is characterized by very low levels of VWF and is associated with profound, life-threatening bleeding. The mode of inheritance in type 3 VWD is autosomal recessive, associated with homozygosity or compound heterozygosity for a defective VWF allele.

The molecular basis of VWD has been established principally for the types 2 and 3 (Nichols and Ginsburg, 1997), but the genetic mechanisms underlying type 1 VWD remain unexplained for the majority of the cases. However in addition to the VWF gene mutations, it is likely that genetic and environmental modifying factors contribute to the incomplete penetrance and variable expressivity of type 1 VWD (Levy and Ginsburg, 2001).

Recently, four single nucleotide polymorphisms (SNPs) in the 5'-regulatory region of the VWF gene have been associated with plasma VWF levels in a normal population (Keightley et al., 1999; Harvey et al., 2000). These polymorphisms were in strong linkage disequilibrium and segregated in two distinct haplotypes. In one of these SNPs, 
the $-1185 \mathrm{~A} / \mathrm{G}$ polymorphism, AA homozygotes were significantly associated with the highest levels of VWF, GG homozygotes showed the lowest levels, and heterozygotes intermediate levels (Keightley et al., 1999).

The present study examined the hypothesis that the $-1185 \mathrm{G}$ allele may be contributing to the phenotype of type $1 \mathrm{VWD}$. The association between the $-1185 \mathrm{~A} / \mathrm{G}$ polymorphism and VWF levels in normal Brazilian individuals was also investigated.

\section{Subjects and Methods}

Subjects. The control group was comprised of 460 unrelated healthy Caucasian volunteers (220 males, $240 \mathrm{fe}-$ males), with no personal or familiar reference of bleeding disease. They were of European ancestry, mainly from Portugual, Spain, Italy and Germany, and consisted of 212 blood donors and 238 students or members of the University staff, living in Porto Alegre, the capital of Brazil's southernmost state. The mean age was 34.1 years $( \pm 15.7$ years).

The patient group consisted of 41 unrelated Caucasian individuals ( 21 males, 20 females), with a mean age of 24.6 years ( \pm 9.8 years), diagnosed with type 1 VWD by Hemostasis Laboratory at the Department of Genetics of the Federal University of Rio Grande do Sul (UFRGS). The diagnosis of VWD was based on clinical history (mucocutaneous bleeding such as epistaxis, bleeding after dental extractions and menorrhagia) and in laboratory findings (decreased plasma VWF levels, correlated decreased plasma FVIII coagulant activity and prolonged bleeding time) (Favaloro and Koutts, 1997). All individuals who agreed to participate in the study were evaluated through a detailed questionnaire which provided information about personal and family bleeding history. Twenty seven patients $(65.9 \%)$ referred other affected individuals in the family and in twelve the pattern was compatible with autosomal dominant inheritance. In the other individuals with familiar recurrence the references were not compatible with definitive pattern of inheritance. In the other families where recurrence occurred, the inheritance could not be defined. There was no reference of consanguineous marriages among the parents of the affected individuals.

Hemostatic Analyses. Plasma VWF antigen (VWF:Ag) was quantified by immunoelectrophoresis using a polyclonal rabbit antihuman VWF antibody (Fischer et al., 1996), the assays being performed at two different plasma dilutions. FVIII procoagulant activity (FVIII:C) was determined by a one-stage clotting assay, using a human FVIII deficient plasma. Bleeding time was measured by the Ivy method.

DNA Analyses. High molecular weight DNA was extracted from whole blood using a non-enzymatic technique (Lahiri and Nurnberger, 1991), and an 864-bp fragment was amplified by polymerase chain reaction (PCR), as previously reported (Simon et al., 2002). DNA fragments were cut with the AccII restriction enzyme, separated by electrophoresis on $1 \%$ agarose gel containing ethidium bromide, and visualized under ultraviolet light. In the absence of a cleavage site AccII digestion yielded one 864-bp band (the A allele) while the presence of a cleavage site resulted in a 668-bp band and a 196-bp band (the G allele).

Statistical Analyses. Allele frequencies were determined by the direct count of the alleles. Departures from the Hardy-Weinberg equilibrium were evaluated by the chisquare $\left(\chi^{2}\right)$ test. The skewness of the plasma VWF:Ag distribution was normalized by logarithmic (log) transformation, although for convenience, back-transformed means and $95 \%$ confidence intervals are reported in the text and tables. The Student's t-test was used to compare VWF levels between individuals of $\mathrm{O}$ and non-O blood groups and between males and females. Allele, genotype and $\mathrm{ABO}$ blood group frequencies of the patients and controls were compared by the $\chi^{2}$ test. Linear regression analysis was used to adjust plasma VWF levels for the age effect. Twoway ANOVA was used to compare age-adjusted VWF levels among genotype groups, with the $\mathrm{ABO}$ blood group as a correction factor. In addition, subjects were divided into two age groups ( $\leq 40$ years and $>40$ years); subgroup analysis was performed using two-way ANOVA, as cited above. In the patients, for analysis of the VWF levels by genotype, we combined the AA and AG genotypes and compared them with GG genotype because the frequency of AA was very low.

\section{Results}

The mean plasma VWF level in type 1 VWD patients was $25.3 \mathrm{U} / \mathrm{dL}$ (95\% CI: 21.3-30.1) while in the control group it was $116.3 \mathrm{U} / \mathrm{dL}$ (95\% CI: 112.0-120.7). As expected, there were significant differences in plasma VWF levels between subjects of $\mathrm{O}(104.9 \mathrm{U} / \mathrm{dL})$ and non-O blood groups $(128.3 \mathrm{U} / \mathrm{dL})$ in the control group $\left(\mathrm{t}_{(458)}=-5.92\right.$, $\mathrm{p}<0.001$ ). In patients, no significant differences were observed in VWF levels between $\mathrm{O}(27.4 \mathrm{U} / \mathrm{dL})$ and non-O subjects $(22.8 \mathrm{U} / \mathrm{dL})\left(\mathrm{t}_{(39)}=0.542, \mathrm{p}=0.466\right)$. Frequencies of $\mathrm{ABO}$ blood groups were significantly different between patients and the control group $\left(\chi^{2}=13.79, p<0.001\right)$, with type 1 VWD patients showing a higher blood group $\mathrm{O}$ frequency $(80 \%)$ than normal subjects $(49 \%)$.

Table 1 shows the allele and genotype frequencies of the $-1185 \mathrm{~A} / \mathrm{G}$ polymorphism in type 1 VWD patient and control groups, the observed genotype frequencies were in Hardy-Weinberg equilibrium for both groups. The $-1185 \mathrm{G}$ allele frequency was $63.4 \%$ in patients and $57.4 \%$ in control individuals $(p=0.29)$. The frequency of the $-1185 \mathrm{G}$ allele in normal Brazilian subjects was lower than those described for other normal Caucasian populations. It was significantly different from those previously reported in Swedish individuals $\left(\mathrm{G}\right.$ allele $\left.=0.71 ; \chi^{2}=12.66, \mathrm{p}<0.001\right)$ (Zhang et al., 1994), from those described by Keightley et 
Table 1 - Allele and genotype frequencies of the $-1185 \mathrm{~A} / \mathrm{G}$ polymorphism of the VWF gene in type 1 VWD patient group $(n=41)$ and control group $(n=460)$.

\begin{tabular}{llccc}
\hline & & Patient group & Control group & $\mathrm{p}$ \\
\hline Allele & $\mathrm{A}$ & $30(36.6)$ & $392(42.6)$ & 0.290 \\
& $\mathrm{G}$ & $52(63.4)$ & $528(57.4)$ & \\
\hline \multirow{4}{*}{ Genotype } & AA & $5(12.2)$ & $85(18.5)$ & \\
& AG & $20(48.8)$ & $222(48.3)$ & 0.549 \\
& GG & $16(39.0)$ & $153(33.2)$ & \\
\hline
\end{tabular}

Values in parentheses are percentages.

al. (1999) for predominantly Caucasian Canadian subjects ( $\mathrm{G}$ allele $\left.=0.64 ; \chi^{2}=6.02, \mathrm{p}=0.014\right)$, and from those described for Dutch subjects $\left(\mathrm{G}\right.$ allele $=0.64 ; \chi^{2}=6.52$, $\mathrm{p}=0.011)$ (Kamphuisen et al., 2001).

Table 2 gives the plasma VWF levels by $-1185 \mathrm{~A} / \mathrm{G}$ genotypes of patients and control subjects. There was no significant association between the $-1185 \mathrm{~A} / \mathrm{G}$ genotypes and the VWF levels in controls. The two-factor ANOVA analysis of the effect of the $-1185 \mathrm{~A} / \mathrm{G}$ polymorphism and ABO blood group on plasma VWF levels showed no significant interaction between these factors $(-1185 \mathrm{~A} / \mathrm{G}$ effect, $\mathrm{F}=0.62, \mathrm{p}=0.54 ; \mathrm{ABO}$ effect, $\mathrm{F}=25.35, \mathrm{p}<0.001$; $-1185 \mathrm{~A} / \mathrm{G}-\mathrm{ABO}$ interaction, $\mathrm{F}=0.73, \mathrm{p}=0.48$ ). In the patients no significant differences were observed in plasma VWF levels between the GG genotype and AA and AG pooled genotypes $\left(\mathrm{t}_{(39)}=0.096, \mathrm{p}=0.758\right)$.

After adjustment for $\mathrm{ABO}$ blood group, a significant age effect in regard to VWF levels was observed in control subjects, with a rise $\sim 10.1 \mathrm{U} / \mathrm{dL}$ for each 10 year increase in age $(p<0.001)$. There were no significant differences in plasma VWF levels with regard to the sex either in control subjects $(p=0.107)$ or in patients $(p=0.741)$. When normal individuals were subgrouped according to age no significant differences were observed in the VWF levels with regard to the different genotypes $(\leq 40$ years: $\mathrm{F}=1.21$, $\mathrm{p}=0.48 ;>40$ years: $\mathrm{F}=0.98, \mathrm{p}=0.65)$. There were no significant differences in the $-1185 \mathrm{~A} / \mathrm{G}$ genotype frequencies when the patients were subgrouped as to the family history $(p=0.423)$ and the clinical symptoms $(p=0.372)$.

\section{Discussion}

Zhang et al. (1994) were the first to describe SNPs in the promoter region of the VWF gene. These authors described four SNPs and studied the association between plasma VWF levels and three of these SNPs but found no association, although this study did not take into account the influence of $\mathrm{ABO}$ blood groups when evaluating plasma VWF levels. Keightley et al. (1999) studied the same three SNPs, which included the $-1185 \mathrm{~A} / \mathrm{G}$ polymorphism, in $\mathrm{O}$ group blood donors and found an association between these SNPs and plasma VWF levels. But, when the sample of 261 Canadian subjects was subgrouped accord-
Table 2 - Mean of plasma VWF levels (U/dL) with regard to the -1185A/G genotypes.

\begin{tabular}{lcrlrr}
\hline \multirow{2}{*}{ Genotype } & \multicolumn{2}{c}{ Patient group } & & \multicolumn{2}{c}{ Control group } \\
\cline { 2 - 3 } \cline { 6 - 6 } & Mean & $95 \%$ CI & & Mean & $95 \%$ CI \\
\hline AA & 28.4 & $22.1-34.7$ & & 122.1 & $112.7-132.5$ \\
AG & 27.1 & $21.9-33.2$ & & 115.8 & $110.0-122.5$ \\
GG & 23.5 & $0-93.4$ & & 113.9 & $106.6-121.5$ \\
\hline
\end{tabular}

ing to age, the significant association between SNPs and VWF levels was maintained only for subjects $>40$ years of age. Similar results were seen in the same sample when another promoter SNP (at nucleotide -1793) was studied (Harvey et al., 2000). Kamphuisen et al. (2001) analyzed the same SNPs studied by Zhang et al. (1994) and did not find any association between them and VWF levels in 301 thrombotic patients and 301 matched healthy controls.

Apart from promoter polymorphisms, data on genetic variation and inter-individual differences in VWF are scarce. Heywood et al. (1996) studied the Ile471Val polymorphism in the VWF gene and found no association between it and the plasma VWF levels in type 2 diabetic patients. Lacquemant et al. (2000) examined three VWF gene polymorphisms in type 1 diabetic patients and found association between the Thr789Ala polymorphism and plasma VWF levels, but these authors suggest that the Ala789 allele may not be the real functional variant associated with the high VWF levels but a marker of this variant. Although different polymorphisms were studied and the results of these studies differ, they have in common the fact that the subjects were diabetic patients, and it is well known that elevated plasma VWF levels are found in diabetic patients (Vischer et al., 1998). Studies on normal individuals have involved only promoter polymorphisms (Zhang et al., 1994; Keightley et al., 1999; Harvey et al., 2000; Kamphuisen et al., 2001), and, as noted above, controversial association results were obtained. Interestingly, Souto et al. (2003) in a genome-wide linkage analysis reported that the structural VWF gene itself had a very low influence on the variability of plasma levels of VWF in a Spanish population.

Our results show that $-1185 \mathrm{~A} / \mathrm{G}$ genotypes, adjusted for $\mathrm{ABO}$ blood group and age effects, were not associated with plasma VWF levels either in normal individuals or in patients. In spite of this, VWF levels were in the same direction as reported by Keightley et al. (1999), with subjects carrying the $\mathrm{G}$ allele having the lower levels. The lack of association in our study could be the result of some specific genotype-environment effect. In this context, age might be considered as an index of changes in a number of environmental factors, such as diet, smoking, and alcohol intake during the lifetime of an individual. These last two factors were reported as affecting the plasma VWF levels (Meena et al., 2000), and may be contributing to the age-associated 
results of Keightley et al. (1999). In our study we found a significant age effect in regard to plasma VWF levels, as has been reported in other studies (Colan et al., 1993; Kamphuisen et al., 1998; Kadir et al., 1999). Although the plasma VWF levels were adjusted for this effect no significant association between the $-1185 \mathrm{~A} / \mathrm{G}$ polymorphism and plasma VWF levels was found.

Mohlke and Ginsburg (1997) have stated that the overlapping distribution of VWF levels observed between normal individuals and type 1 VWD patients suggest that VWD should be viewed more appropriately as a complex trait. As in other complex traits, it may not be possible to define a clear threshold plasma VWF level that distinguishes type $1 \mathrm{VWD}$ patients from normal subjects or that accurately predicts the development of symptoms. The $\mathrm{ABO}$ blood group is the main genetic variable known to be involved in the plasma VWF levels, and our data showed that there were significantly more $\mathrm{O}$ blood group individuals among type 1 VWD patients, as previously reported (Gill et al., 1987). Several studies have shown that O blood group individuals have, on average, lower VWF levels than non-O blood group individuals (Gill et al., 1987; Shima et al., 1995; Kamphuisen et al., 1998; Souto et al., 2000), and perhaps, the O blood group trait and some SNPs in VWF gene would act in an addictive way to decrease VWF levels. This would account for some of the type 1 VWD patients, mainly those nearest to the lower limit of the normal distribution.

Our study was, for the first time, concerned with the relationship between VWD and the $-1185 \mathrm{~A} / \mathrm{G}$ polymorphism, the data showing that type 1 VWD patients do not have a higher $\mathrm{G}$ allele frequency than control subjects. Few mutations have been detected in type 1 VWD families, despite the efforts in this direction. The great majority of mutations described in type 1 VWD refer to null alleles segregating in type 3 VWD genealogies (Zhang et al., 1992; Eikenboom et al., 1993, 1998). Heterozygous relatives of type 3 VWD patients with a single null allele can exhibit a considerable variability, either being asymptomatic or exhibiting a type 1 VWD phenotype (Zhang et al., 1995). This variability shows that the normal allele may have a significant influence on VWD expression. Furthermore, only two mutations, both disrupting cysteine pairing in the D3 domain of the VWF gene, have been associated with classical dominant type 1 VWD (Eikenboom et al., 1996; Castaman et al., 2000), but, as with the null alleles, this does not appear a common event in type 1 VWD (Coughlan et al., 1999; Keeney et al., 1999).

In conclusion, our data does not support the hypothesis that the $-1185 \mathrm{~A} / \mathrm{G}$ polymorphism plays a role in the development of type 1 VWD disease, and apart from this, polymorphism was not associated with levels of VWF in normal Brazilian individuals. The role of other SNPs in the VWF gene should be investigated further.

\section{Acknowledgments}

This research was supported by the Programa de Apoio a Núcleos de Excelência (PRONEX), Financiadora de Estudos e Projetos (FINEP), and Conselho Nacional de Desenvolvimento Científico e Tecnológico (CNPq).

\section{References}

Castaman G, Eikenboom JCJ, Missiaglia E and Rodeghiero F (2000) Autossomal dominant type 1 von Willebrand disease due to G3639T mutation (C1130F) in exon 26 of von Willebrand factor gene: description of five Italian families and evidence for a founder effect. Br J Haematol 108:876879.

Conlan MG, Folsom AR, Finch A, Davis CE, Sorlie P, Marcucci G and Wu KK (1993) Associations of factor VIII and von Willebrand factor with age, race, sex, and risk factors for atherosclerosis. The Atherosclerosis Risk in Communities (ARIC) study. Thromb Haemost 70:380-385.

Coughlan TC, Blagg JL, Abulola M, Daly ME, Hampton KK, Makris M, Peake IR and Goodeve AC (1999) Null alleles are not a common cause of type 1 von Willebrand disease in the British population. Thromb Haemost 82:1373-1375.

Eikenboom JCJ, Reistma PH, Peerlinck KMJ and Briët E (1993) Recessive inheritance of von Willebrand's disease type 1 . Lancet 341:982-986.

Eikenboom JCJ, Matsushita T, Reistma PH, Tuley EA, Castaman G, Briet E and Sadler JE (1996) Dominant type 1 von Willebrand disease caused by mutated cysteine residues in the D3 domain of von Willebrand factor. Blood 88:24332442.

Eikenboom JCJ, Castaman G, Vos HL, Bertina RM and Rodeghiero F (1998) Characterization of the genetic defects in recessive type 1 and type 3 von Willebrand disease patients of Italian origin. Thromb Haemost 79:709-717.

Favaloro EJ and Koutts J (1997) Laboratory assays for von Willebrand factor: relative contribution to the diagnosis of von Willebrand's disease. Pathology 29:385-391.

Fischer RR, Lucas EM, Pereira AMB and Roisenberg I (1996) Preparation of a heterologous antiserum for the determination of von Willebrand factor in human plasma. Braz J Med Biol Res 29:1641-1644.

Gill JC, Endres-Brooks J, Bauer PJ, Marks Jr WJ and Montgomery RR (1987) The effect of ABO blood group on the diagnosis of von Willebrand disease. Blood 69:1691-1695.

Harvey PJ, Keightley AM, Lam YM, Cameron C and Lillicrap D (2000) A single nucleotide polymorphism at nucleotide -1793 in the von Willebrand factor (VWF) regulatory region is associated with plasma VWF:Ag levels. Br J Haematol 109:349-353.

Heywood DM, Mansfield MW and Grant PJ (1996) Levels of von Willebrand factor, insulin resistance syndrome, and a common VWF gene polymorphism in non-insulin-dependent (type 2) diabetes mellitus. Diabetic Med 13:720-725.

Kadir RA, Economides DL, Sabin CA, Owens D and Lee C (1999) Variations in coagulation factors in women: effects of age, ethnicity, menstrual cycle and combined oral contraceptive. Thromb Haemost 82:1456-1461.

Kamphuisen PW, Houwing-Duistermaat JJ, van Houwelingen HC, Eikenboom JCJ, Bertina RM and Rosendaal FR (1998) 
Familial clustering of factor VIII and von Willebrand factor levels. Thromb Haemost 79:323-327.

Kamphuisen PW, Eikenboom JCJ, Rosendaal FR, Koster T, Blann AD, Vos HL and Bertina RM (2001) High factor VIII antigen levels increase the risk of venous thrombosis but are not associated with polymorphisms in the von Willebrand factor and factor VIII gene. Br J Haematol 115:156-158.

Keeney S, Cumming A and Hay C (1999) Mutations in von Willebrand factor multimerization domains are not a common cause of classical type 1 von Willebrand disease. Thromb Haemost 82:1446-1450.

Keightley AM, Lam YM, Brady JN, Cameron CL and Lillicrap D (1999) Variation at the von Willebrand factor (VWF) gene locus is associated with plasma VWF:Ag levels: identification of three novel single nucleotide polymorphisms in the VWF gene promoter. Blood 93:4277-4283.

Lacquemant C, Gaucher C, Delorme C, Chatellier G, Gallois Y, Rodier M, Passa P, Balkau B, Mazurier C, Marre M and Froguel P (2000) Association between high von Willebrand factor levels and the Thr789Ala VWF gene polymorphism but not with nephropathy in type I diabetes. Kidney Int 57:1437-1443.

Lahiri DK and Nurnberger JI Jr (1991) A rapid non-enzimatic method for preparation of HMW DNA from blood for RFLP studies. Nucleic Acids Res 19:5444.

Levy G and Ginsburg D (2001) Getting at the variable expressivity of von Willebrand disease. Thromb Haemost 86:144-148.

Meena K, Marmot M and Brunner E (2000) Social determinants of von Willebrand factor: The Whitehall II study. Arterioscler Thromb Vasc Biol 20:1842-1847.

Mohlke KL and Ginsburg D (1997) von Willebrand disease and quantitative variation in von Willebrand factor. J Lab Clin Med 130:252-261.

Nichols WC and Ginsburg D (1997) von Willebrand disease. Medicine 76:1-20.

Rodeghiero F, Castaman G and Dini E (1987) Epidemiological investigation of the prevalence of von Willebrand's disease. Blood 69:454-459.

Sadler JE (1994) A revised classification of von Willebrand disease. Thromb Haemost 71:520-525.
Sadler JE, Matsushita T, Dong Z, Tuley EA and Westfield LA (1995) Molecular mechanism and classification of von Willebrand disease. Thromb Haemost 74:161-166.

Shima M, Fujimura Y, Nishiyama T, Tsujiuchi T, Narita N, Matsui T, Titani K, Katayama M, Yamamoto $\mathrm{F}$ and Yoshioka A (1995) ABO blood group genotype and plasma von Willebrand factor in normal individuals. Vox Sang 68:236-240.

Simon D, Palatnik M and Roisenberg I (2002) Analysis of the $-1185 \mathrm{~A} / \mathrm{G}$ von Willebrand factor (VWF) gene polymorphism in two Brazilian ethnic groups and its effect on the plasma VWF levels. Thromb Res 105:519-522.

Souto JC, Almasy L, Muñiz-Diaz E, Soria JM, Borrell M, Bayen L, Mateo J, Madoz P, Stone W, Blangero J and Fontcuberta J (2000) Functional effects of the ABO locus polymorphism on plasma levels of von Willebrand factor, factor VIII, and activated partial thromboplastin time. Arterioscler Thromb Vasc Biol 20:2024-2028.

Souto JC, Almasy L, Soria JM, Buil A, Stone W, Lathrop M, Blangero J and Fontcuberta J (2003) Genome-wide linkage analysis of von Willebrand factor plasma levels: results from the GAIT project. Thromb Haemost 89:468-474.

Vischer UM, Emeis JJ, Bilo HJG, Stehouwer CDA, Thomsen C, Rasmussen O, Hermansen K, Wollheim CB and Ingerslev J (1998) von Willebrand factor (vWf) as a plasma marker of endothelial activation in diabetes: improved reliability with parallel determination of the vWf propeptide (vWf:AgII). Thromb Haemost 80:1002-1007.

Werner EJ, Broxson EH, Tucker EL, Giroux DS, Shults J and Abshire TC (1993) Prevalence of von Willebrand disease in children: A multiethnic study. J Pediatric 123:893-898.

Zhang ZP, Lindstedt M, Falk G, Blombäck M, Egberg N and Anvret M (1992) Nonsense mutations of the von Willebrand factor gene in patients with von Willebrand disease type III and type I. Am J Hum Genet 51:850-858.

Zhang ZP, Blombäck M, Egberg N, Falk G and Anvret M (1994) Characterization of the von Willebrand factor gene (VWF) in von Willebrand disease type III patients from 24 families of Swedish and Finnish origin. Genomics 21:188-193.

Zhang ZP, Lindstedt M, Blombäck M and Anvret M (1995) Effects of the mutant von Willebrand factor gene in von Willebrand disease. Hum Genet 96:388-394.

Editor: Angela M. Vianna-Morgante 